\title{
COMPARISON BETWEEN THE LINGUALLY BASED AND THE BUCCALLY BASED TRIANGULAR FLAP DESIGN IN THE SURGICAL REMOVAL OF IMPACTED MANDIBULAR THIRD MOLARS (CLINICAL TRIAL)
}

\author{
Nesma M. Said ${ }^{1} B D S$, Saeeda M. Osman ${ }^{P} P D$, Ahmed O. Sweedan ${ }^{3} P h D$
}

\section{ABSTRACT}

INTRODUCTION: Removal of wisdom teeth could be challenging owning to limited accessibility, the tooth's structural location and probable nerve damage especially to the inferior alveolar nerve and the lingual nerve.

OBJECTIVES: The primary goal of this study is to make a comparison between the lingually based triangular flap and the buccally based triangular flap in terms of post-operative healing and complications.

METHODS: 20 patients between the age of 21 and 30 years were randomly selected for mandibular third molar removal from clinic of the Oral and Maxillofacial Department, Faculty of Dentistry, Alexandria University. They were divided into two groups the study group (n=10) was operated using the lingually based triangular flap design and the control group $(n=10)$ was operated using the buccally based triangular flap design. The patients were recalled on the $2^{\text {nd }}, 7^{\text {th }}$ and $14^{\text {th }}$ days postoperatively in order to evaluate postoperative pain ,swelling ,wound dehiscence , the incidence of dry socket formation and lingual nerve injury.

RESULTS: The lingually based triangular flap showed inferior levels of pain and was statistically significant in the 3rd and $7^{\text {th }}$ day postoperatively . The lingually based triangular flap design showed less amount of facial swelling and lower incidence of wound dehiscence, dry socket formation and lingual nerve injury but the difference between the groups was all statistically insignificant.

CONCLUSION: Lingually based triangular flap design revealed better postoperative healing than buccally based triangular flap design. KEYWORDS: Lingual Triangular Flap, Buccal Triangular, Impaction, Mandibular Molar.

1.BDS, 2008, Faculty of Dentistry, Alexandria University, Egypt.

2.Professor of Oral and Maxillofacial Surgery, Department of Oral and Maxillofacial Surgery Faculty of Dentistry, Alexandria University, Egypt.

3.Lecturer of Oral and Maxillofacial Surgery, Department of Oral and Maxillofacial Surgery Faculty of Dentistry, Alexandria University, Egypt.

*Corresponding author nesma.riham@yahoo.com

\section{INTRODUCTION}

Many flap designs used for impacted third molar surgery do not place the lines of incisions on sound bone, as they involve incisions that are placed on the extraction socket resulting in a higher incidence of mucosal dehiscence , followed by secondary wound healing.

Extraction of mandibular third molars might be a difficult procedure owing to the narrow accessibility, anatomical location and possible injury to the neighboring vital structures like the inferior alveolar nerve, the lingual nerve and the neighboring teeth $(1,2)$

One of the important aspects in determining the severity of postoperative complications is the length of surgery. Pain, swelling, and trismus are caused by surgical trauma which activates the inflammatory response. The time taken in removal of mandibular third molar depends on the anatomical position of the tooth, angle of impaction amount of overlying tissue and bone, the skill of specialist, and the operating technique used. The previous aspects control the length of surgery it also affects the time and severity of postoperative complications $(3,4,5)$.Consequently, many surgical methods have been tried to reduce these complications, such as the use of surgical drains, different suturing techniques, and numerous flap designs. For an ideal flap design all lines of incisions should be located on sound bone nevertheless most flap designs don't follow this rule with the incisions ends up being on the bony defect created by the extraction socket which causes mucosal dehiscence. In this circumstance, the buccal flap is inserted into the extraction socket disturbing clot establishment leading to delayed wound healing and a greater chance for dry socket 
formation which caused longer periods of pain and anxiety to the patient postoperatively $(6,7,8)$.

The only flap designs that place all lines of incisions on sound bone are Negeshwar comma shape flap, Berwicke's tongue shaped flap and the lingually based triangular flap design evaluated in this study. In the lingually based triangular flap design the lines of incisions are placed on the anterior border of the mandible away from the bony defect created by the extraction socket which decreases the levels of postoperative pain ,swelling and the incidence of wound dehiscence ,dry socket formation. $(9,10)$

The incision of soft tissue has to be designed so as to provide sufficient access, not to damage the surrounding anatomical structures, in particular, the lingual nerve and to allow a correct and possibly easy suture.

In addition, when the surgical site is left exposed in the oral cavity and not covered by a gingival flap it can this may lead to infection in the surgical site a condition known as alveolar ostitis, Hence, existing wound dehiscence at the distofacial edge of the second molar probable prolong the post-surgical treatment period this may lead to elevated level and duration of postoperative pain and discomfort. Furthermore, potential periodontal complications distal to the preceding second molar. (11)

Various buccal flaps (triangular, envelop, etc.) has been documented in the literature for performing impacted third molar surgery, the envelope flap is the most commonly used and preferred flap designs in impacted third molar surgery. The aim of this study is to compare the lingually based with the buccally based triangular flap design in the surgical removal of mandibular third molars.

The null hypothesis of this study states that there is no statistical difference in the postoperative outcomes when using the lingually based triangular flap rather than the buccally based triangular flap design.

\section{MATERIALS AND METHODS}

Study design: The study strategy is a randomized and prospective clinical trial.

Study sample: The clinical trial was performed at the inpatient clinic of the oral and Maxillofacial Surgery Department, Faculty of Dentistry, Alexandria University. It involved 20 patients with an impacted Mandibular third molar that is misally positioned (Class II position B). Before performing surgery, the surgical and postoperative study protocol was explained to all patients involved in this study patients were allocated in a random style into two groups.

Method of randomization: SAS Random Number Generators were utilized to create the randomization sequence. The allocation sequence was hidden from those assigning members to groups, until the second of the assignment.

Sample size estimation: A minimal total sample size of sixteen male patients (Eight per group) is required to identify an average significant difference in pain score (VAS) among the group (A) and group (B) taking in consideration $80 \%$ power and 95 confidence level via a Chi Square-test. (PASS program version) (12).

All measures were completed in agreement with Ethic research board, Faculty of Dentistry, Alexandria college

\section{Eligibility Criteria's}

- Existence of impacted wisdom tooth that is mesially angulated and retained in bone (class II position B).

- Patient age from 21 to 30 years old.

Omission criteria

- Patients with systemic disease (diabetes, renal failure, immunocompromised patients, cardiac patients and patients taking radiotherapy or chemotherapy).

- Heavy Smoking.

- Pregnancy or lactation

Materials used

- Round, and fissure carbide bur (manufactured by Dent Supply Sirona, Germany) for bone removal.

- 3-0 silk sutures. (manufactured by Goldenwell, China )

- Caliber. (manufactured by Dent Supply Sirona, Germany )

- Straight apexo elevator. (manufactured by Dent Supply Sirona, Germany)

Pre-operative assessment and examination

Complete medical and dental history was including; name, age, sex, job, address, and date was taken for each patient.

\section{Clinical examination}

A thorough clinical examination by inspection and palpation was completed to all patients to decide the overall periodontal and oral health state and for detection of any infection or pathology that influenced the sequence of wound healing for example (abscess and pericoronitis) $(13,14,15)$.

\section{Radiographic examination}

All patients performed a panoramic x-ray before surgery to examine the anatomical location of the impacted third molar and for the discovery of any current pathology.

Preoperative preparation:

A diluted povidone-iodine solution was used to rinse thoroughly for 30 secs before the process to decrease microbial contamination. Then local anesthesia was administered which consist of lignocaine which was used to anesthetize the inferior alveolar, the lingual nerve $(2 \mathrm{ml})$, and the long buccal nerve $(1 \mathrm{ml})(16,17)$.

Operative phase

Group A (The control group $(n=10)$ )

The conventional flap design was used (buccally based triangular flap). The incision began from the crest of the alveolar crest to the mesial side of the mandibular third molar. (Figure 1). (18)

It terminated with a releasing vertical incision which inclines in a slanting mesial direction on the vestibular fornix. (19)

Group B (The study group study $(n=10))$

Lingually based triangular flap design was done. An oblique incision was made along the anterior border of mandibular 
ramus this incision is made in an anterior direction. A second oblique incision is made distal to the mandibular second molar in a posterior direction to meet the first incision at the depth of the gingival sulcus to form a triangle. (19) (Figure 2)

For both groups a mucoperiosteal flap was reflected (Figure 3) followed by bone removal using a high-speed handpiece a surgical bur is used to remove the bone in abundant irrigation with $0.9 \%$ sterile saline.

The molar was sectioned by a surgical bur followed by tooth elevation using a straight apexo elevator. (Figure 4) - Suturing was done utilizing 3-0 silk stitches (Figure 5).

\section{Post-operative care and follow up}

\section{Post-operative Medications:}

Patients were prescribed Paracetamol 500mg (Panadol: manufactured by Uni Pharma, U.S.A.); 1 tablets every 8 hours for 5 day. In addition to Chlorhexidine Gluconate/benzydamine chloride mouth wash (Listerine: manufactured by, Johnson \& Johnson, U.S.A.); twice a day. The patients were also prescribed Amoxicillin clavulanate 1gm (Augmentin: manufactured by, GlaxoSmithKline, England.); 1 capsule every 12 hours for 3 days postoperatively $(20,21)$

\section{Postoperative Evaluation}

Patients were requested to return and were assessed for the factors of pain, wound dehiscence, facial inflammation, extreme mouth opening, dry socket development and potential harm to the lingual nerve (9).

\section{Postoperative pain:}

The visual analog scale was utilized to gauge the degree of post-operative pain with a scale from 0 to 10 at $6 \mathrm{hr}, 12 \mathrm{hr}$ postoperatively and for 7 days after the extraction.

\section{Postoperative swelling:}

For evaluating inflammation, five spaces were gauged: The space from the mandibular angle to the side angle of the mouth, the space from the mandibular angle to the nasal alar curvature ,the space from the mandibular angle to the lateral canthus of the eye, the space from the tragus to the delicate tissue pogonion and the space from the tragus to the side angle of the mouth.

\section{Trismus}

Trismus was evaluated by measuring the extreme interincisional opening (in millimeters) on days 2,7, and14 postoperatively (22).

\section{Wound Dehiscence}

Wound healing was evaluated by measuring the amount of wound dehiscence as every opening along the line of incision was identified and recorded on days 2,7,14 postoperatively.

\section{Statistical Analysis of the data}

Records were inserted into the computer and evaluated via International Business Machines Statistical Package for the Social Sciences (IBM SPS) software platform version 20.0.(Armonl, NY: IBM Corp) Qualitative data were designated by number and percent. Quantitative data were styled using range (minimum and maximum), mean, median and standard deviation.
The used tests were:

1- Chi-square test.

2- Student t-test.

3- Mann Whitney test.

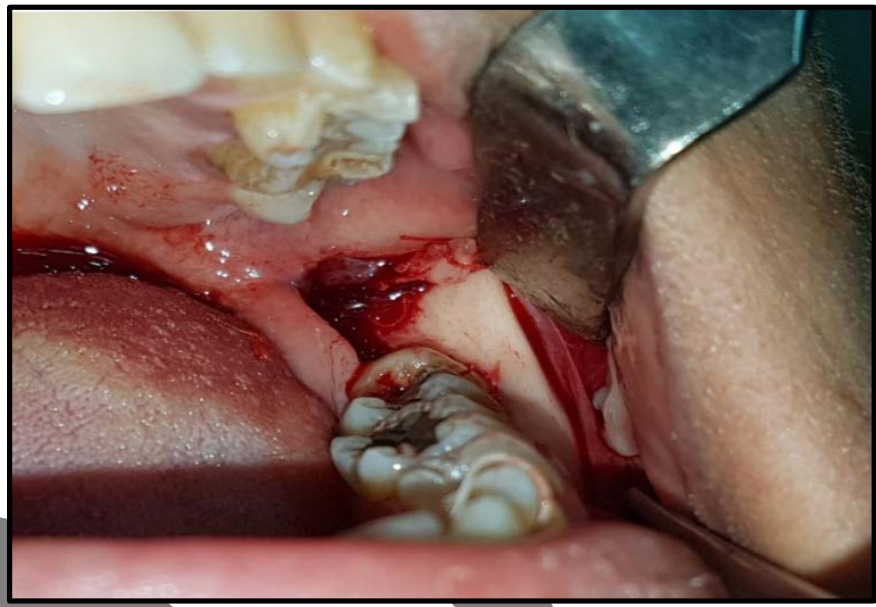

Figure (1): Clinical picture showing elevation of buccally based triangular flap.

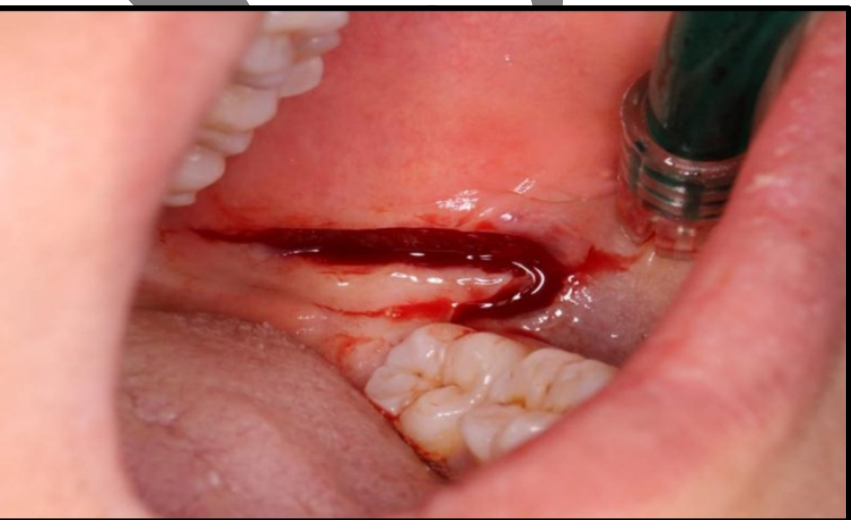

Figure (2): Clinical picture showing the lingually based triangular flap design.

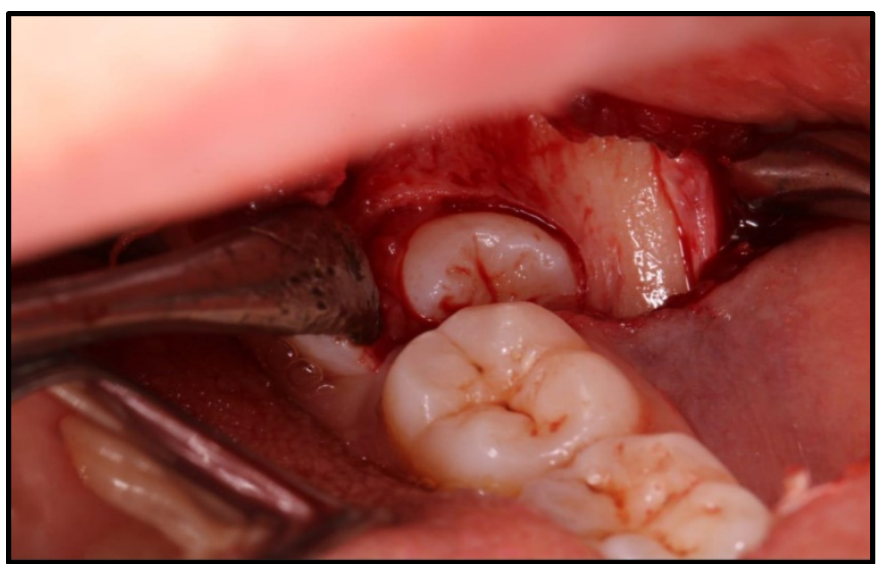

Figure (3): Clinical picture showing elevation of the mucoperiosteal flap. 


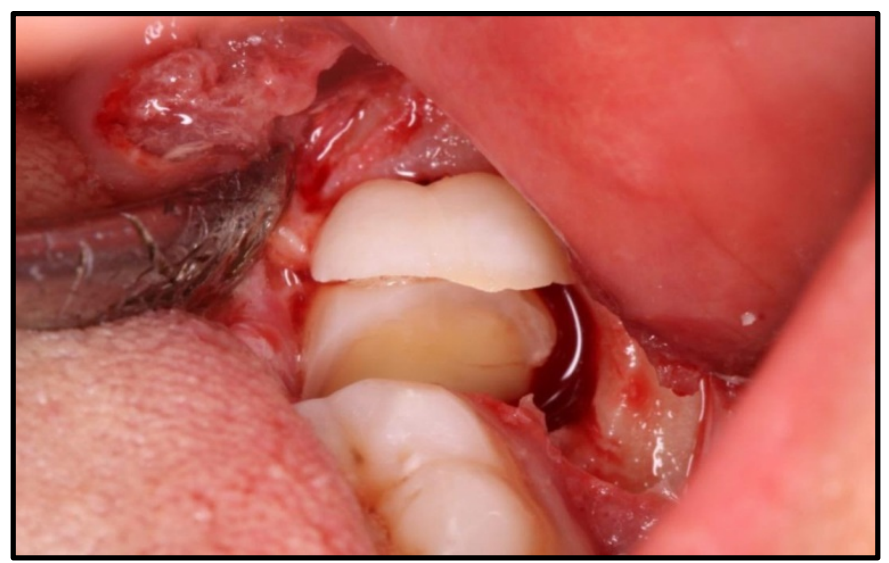

Figure (4): Clinical picture demonstrating mesial lock removal and bone guttering.

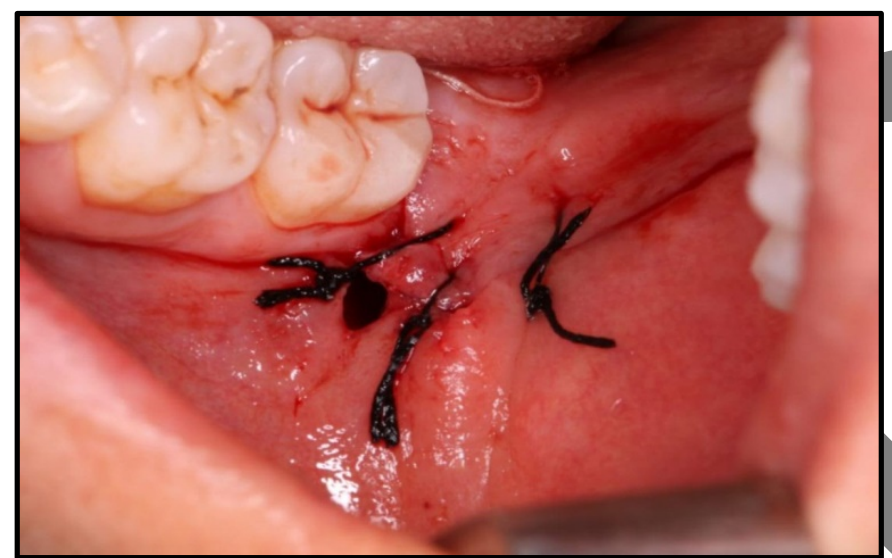

Figure (5): Clinical picture showing suturing of the lingually based triangular flap.

\section{RESULTS}

An overall of 20 patients (11 males and nine females), with age ranging from 21 and 30 years (mean \pm standard deviation,27.10 \pm 3.0 years for the study group and26.80 \pm 6.14 for the control group) joined in this study. (Table 1 ) Trismus

The mean maximal interincisal opening was $38.20 \pm$ $5.69 \mathrm{~mm}$ in the control group and was $38.40 \pm 5.30 \mathrm{~mm}$ in the study group preoperatively. Postoperatively for the study group the mean maximal interincisal opening was $34.20 \pm$ $5.67 \mathrm{~mm}, 36.80 \pm 5.47 \mathrm{~mm}$ and $38.40 \pm 5.06 \mathrm{~mm}$ on the $2^{\text {nd }}$ , $7^{\text {th }}$ and $14^{\text {th }}$ days, respectively. for the control group. The mean maximal interincisal opening was $32.10 \pm 5.17 \mathrm{~mm}$ ,34.40 $\pm 5.52 \mathrm{~mm}$ and $37.60 \pm 5.93 \mathrm{~mm}$ for the corresponding days, respectively. The difference in mouth opening between the two flap designs was not statistically significant $(p>.05)$. There was a superior recovery in the extent of the extreme mouth opening in the lingually based triangular flap, nevertheless, it was not statistically significant.

Pain:

Mean values of the VAS scores for the control group at $6 \mathrm{hr}, 12 \mathrm{hr}$ postoperatively were $9.40 \pm 0.84 \mathrm{~mm}$ and
$8.20 \pm 1.48 \mathrm{~mm}$ respectively and for the study group at the same times was $9.40 \pm 0.70 \mathrm{~mm}$ and $8.0 \pm 1.25 \mathrm{~mm}$

Mean values of the VAS scores for the control group on the $1^{\text {st }}, 2^{\text {nd }}, 3^{\text {rd }}, 4^{\text {th }}, 5^{\text {th }}, 6^{\text {th }}$ and $7^{\text {th }}$ days postoperatively were 7.80 $\pm 1.62 \mathrm{~mm}, 7.10 \pm 1.73 \mathrm{~mm}, 6.10 \pm 1.73 \mathrm{~mm}, 4.90 \pm 2.08 \mathrm{~mm}$, $3.70 \pm 2.11 \mathrm{~mm}, 2.60 \pm 1.96 \mathrm{~mm}$ and $1.80 \pm 1.48 \mathrm{~mm}$ and for the study group were $6.90 \pm 1.20 \mathrm{~mm}, 5.80 \pm 1.48 \mathrm{~mm}, 4.30 \pm$ $1.57 \mathrm{~mm}, 3.50 \pm 1.51 \mathrm{~mm}, 2.60 \pm 1.43 \mathrm{~mm}, 1.90 \pm 1.20 \mathrm{~mm}$ and $0.60 \pm 0.97 \mathrm{~mm}$ at the corresponding days

Lingually based triangular flap showed inferior levels of pain and was statistically significant in the 3rd and 7 th day postoperatively. $(\mathrm{P}<0.05)$ (Figure 6$)$.

Postoperative swelling:

Mean values of the facial swelling for the control group on the $, 2^{\text {nd }}, 7^{\text {th }}$ and $14^{\text {th }}$ days were $0.90 \pm 0.42 \mathrm{~mm}, 0.43 \pm$ $0.26 \mathrm{~mm}$ and $0.11 \pm 0.09 \mathrm{~mm}$ and for the study group were $0.63 \pm 0.18 \mathrm{~mm}, 0.29 \pm 0.14 \mathrm{~mm}$, and $0.04 \pm 0.04 \mathrm{~mm}$ at the corresponding day. The reduction in facial swelling was slightly better in the lingually based flap but the difference was statistically insignificant (Table 2).

Wound Dehiscence:

At the study group only 4 cases demonstrated wound dehiscence meanwhile the control group 8 cases demonstrated wound dehiscence along the suture lines The incidence of wound dehiscence was less when using lingually based triangular flap design nonetheless it was statistically insignificant.

Dry socket Formation:

It was noticed that the majority of cases that ended up with dry socket were in the control group however, the difference was statistically insignificant. Only one case at the control group ended up with dry socket formation and none of the study group cases showed any signs of developing dry socket.

Lingual Nerve Injury:

The chances of preserving the lingual nerve were higher in the study group but the difference was statistically insignificant. As only two cases in the control group showed signs of lingual nerve injury and none of the study group cases showed any signs of lingual nerve injury (Table 3).

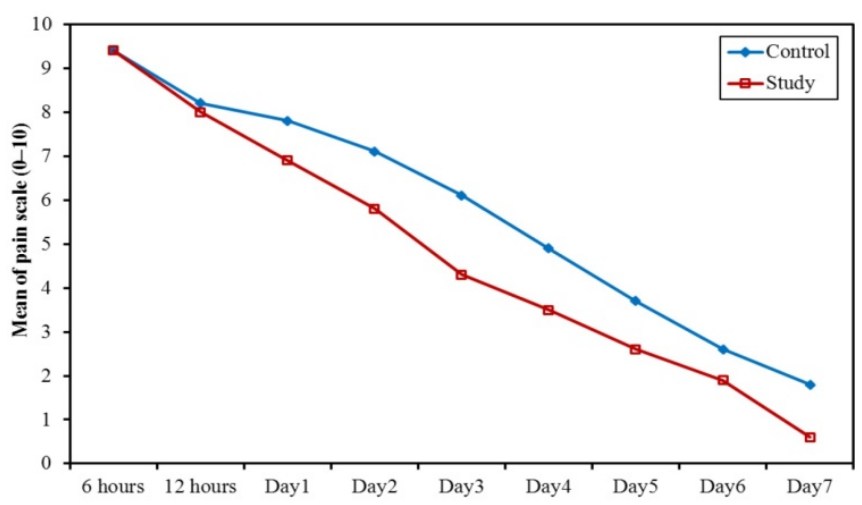

Figure (6): Comparison between the two studied groups according to pain scale. 
Table (1): Comparison between the two studied groups according to demographic data.

\begin{tabular}{|c|c|c|c|c|c|c|}
\hline & \multicolumn{2}{|c|}{$\begin{array}{l}\begin{array}{l}\text { Control } \\
(\mathrm{n}=10)\end{array} \\
\end{array}$} & \multicolumn{2}{|c|}{$\begin{array}{l}\text { Study } \\
(n=10)\end{array}$} & \multirow{2}{*}{$\begin{array}{l}\text { Test of } \\
\text { sig. }\end{array}$} & \multirow{2}{*}{$\mathrm{p}$} \\
\hline & No. & $\%$ & No. & $\%$ & & \\
\hline $\begin{array}{l}\text { Gender } \\
\text { Male } \\
\text { Female }\end{array}$ & $\begin{array}{l}6 \\
4 \\
\end{array}$ & $\begin{array}{l}60.0 \\
40.0\end{array}$ & $\begin{array}{l}5 \\
5\end{array}$ & $\begin{array}{l}50.0 \\
50.0\end{array}$ & $\chi^{2}=0.202$ & $\begin{array}{l}{ }^{\mathrm{FE}} \mathrm{p}= \\
1.000\end{array}$ \\
\hline $\begin{array}{l}\text { Age } \\
\text { (years) } \\
\text { Min. } \\
\text { Max. }\end{array}$ & \multicolumn{2}{|c|}{$\begin{array}{l}23.0 \\
32.0\end{array}$} & \multicolumn{2}{|c|}{$21.0-38.0$} & & \\
\hline $\begin{array}{l}\text { Mean } \quad \pm \\
\text { SD. } \\
\text { Median } \\
\text { (IQR) }\end{array}$ & $\begin{array}{l}27.10 \\
3.0 \\
26.50\end{array}$ & \pm & \multicolumn{2}{|c|}{$\begin{array}{l}26.80 \quad \pm \\
6.14\end{array}$} & $\mathrm{t}=0.139$ & 0.892 \\
\hline
\end{tabular}

$\chi^{2}$ : Chi square test $\quad$ FE: Fisher Exact t: Student t-test $\mathrm{p}$ : $\mathrm{p}$ value for comparing between the two studied groups

Table (2): Comparison between the two studied groups according to swelling.

\begin{tabular}{|c|c|c|c|c|}
\hline Swelling & $\begin{array}{l}\begin{array}{l}\text { Control } \\
(n=10)\end{array} \\
\end{array}$ & $\begin{array}{l}\text { Study } \\
(n=10)\end{array}$ & & $\mathbf{p}$ \\
\hline $\begin{array}{l}\text { Day } 2 \\
\text { Min. - Max. } \\
\text { Mean } \pm \text { SD. } \\
\text { Median } \\
\text { (IQR) }\end{array}$ & $\begin{array}{l}0.40-1.80 \\
0.90 \pm 0.42 \\
0.82 \quad(0.54 \quad- \\
1.06)\end{array}$ & $\begin{array}{l}0.44-0.96 \\
0.63 \pm 0.18 \\
0.56 \quad(0.50 \quad- \\
0.72)\end{array}$ & 29.0 & \\
\hline $\begin{array}{l}\text { Day } 7 \\
\text { Min. - Max. } \\
\text { Mean } \pm \text { SD. } \\
\text { Median } \\
\text { (IQR) }\end{array}$ & $\begin{array}{l}0.06-1.06 \\
0.43 \pm 0.26 \\
0.39 \quad(0.32 \\
0.50)\end{array}$ & $\begin{array}{l}0.06-0.52 \\
0.29 \pm 0.14 \\
0.30 \quad(0.18 \\
0.38)\end{array}$ & 31.0 & 0.150 \\
\hline $\begin{array}{l}\text { Day } 14 \\
\text { Min. - Max. } \\
\text { Mean } \pm \text { SD. } \\
\text { Median } \\
\text { (IQR) } \\
\end{array}$ & $\begin{array}{ll}0.0-0.26 \\
0.11 \pm 0.09 \\
0.08 \quad(0.02 \quad- \\
0.18)\end{array}$ & $\begin{array}{ll}0.04 \pm 0.04 \\
0.03 \quad(0.0 \\
0.06)\end{array}$ & & \\
\hline
\end{tabular}

\section{U: Mann Whitney test}

$\mathrm{p}$ : $\mathrm{p}$ value for comparing between the two studied groups

Table (3) Comparison between the two studied groups according to the incidence of lingual nerve injury.

\begin{tabular}{|c|c|c|c|c|c|c|}
\hline \multirow{2}{*}{$\begin{array}{l}\text { The incidence } \\
\text { of lingual nerve } \\
\text { injury }\end{array}$} & \multicolumn{2}{|c|}{$\begin{array}{l}\text { Control } \\
(\mathrm{n}=10)\end{array}$} & \multicolumn{2}{|c|}{$\begin{array}{l}\text { Study } \\
(n=10)\end{array}$} & \multirow[t]{2}{*}{$\chi^{2}$} & \multirow[t]{2}{*}{${ }^{\mathrm{FE}} \mathbf{p}$} \\
\hline & No. & $\%$ & No. & $\%$ & & \\
\hline $\begin{array}{l}\text { No } \\
\text { Yes }\end{array}$ & $\begin{array}{l}8 \\
2\end{array}$ & $\begin{array}{l}80.0 \\
20.0\end{array}$ & $\begin{array}{l}10 \\
0\end{array}$ & $\begin{array}{l}100.0 \\
0.0\end{array}$ & 2.222 & 0.474 \\
\hline
\end{tabular}

$\chi^{2}$ : Chi square test

FE: Fisher Exact

$\mathrm{p}$ : p value for comparing between the two studied groups

\section{DISCUSSION}

In this study, the postoperative outcomes of the lingually based triangular flap, were compared to those following the use of the traditional buccally based triangular flap. In this study, to standardize the surgical protocol and to decrease the effects of variables on the outcomes, all surgeries were performed by a single surgeon under similar clinical conditions. Furthermore, patients were selected from a similar age group. Thus, the flap design was the sole independent factor associated with the severity of postoperative morbidities; it was attempted to eliminate the patient compliance factor, and all other possible factors were kept as homogeneous as possible. (23)

It was found that the pain levels in the lingually based triangular flap group were lower than the buccally based triangular flap group the difference was statistically significant in the $3^{\text {rd }}$ and $7^{\text {th }}$ day postoperatively the lower pain levels may be due to the decreased soft tissue trauma because the lingually based triangular design place all the lines of incision on sound bone which is similar to the design of the comma-shaped flap described by Nageshwar and the tongue-shaped flap designed by Berwick.So when Nageshwar compared the conventional modified envelope flap with comma-shaped flap designs he also found that pain scores were significantly lower when the comma-shaped flap design technique was used. Also, it was found that the incidence of swelling and trismus was lower in the commashaped flap group, but this was not statistically significant. We agreed with his results (23).

In this study The postoperative facial swelling was slightly less in the lingually based flap but the difference was statistically insignificant.in Kumar et al study on the comma shaped flap which also places all lines of incisions of sound bone like the lingually based triangular design .they compared the effects of the comma-shaped flap design and standard flap design (Ward's incision) on pain, swelling, and trismus after impacted third molar surgery. They observed that the comma-shaped flap was associated with lesser facial swelling, lower pain scores, and a lower incidence of trismus. Which is consistent with our results? (24).

In this study there was a better recovery in the mouth opening in the lingually based flap, but the difference was statistically insignificant. There have been many studies on the morbidities following surgical removal of impacted mandibular third molars. Postoperative complications of impacted third molar surgery such as pain, swelling, trismus, and alveolar osteitis, adversely affect the patient's quality of life. As a consequence, different surgical strategies such as various flap designs, different closure techniques, the use of drugs and ice packs, surgical drains, and laser applications have been used to prevent or minimize these postoperative complications. (19).

Yolcu et al. applied the lingual based triangular flap technique and buccal-based triangular flap technique to 22 patients in their study for extracting the impacted third molar. They could not find a statistically significant difference 
between the two flap techniques in swelling and trismus. However, the pain levels in the lingual-based triangular flap technique were statistically higher in the postoperative 12th hour than the buccal based triangular flap technique. Our results were similar to this study in terms of postoperative swelling and trismus however the pain levels in our study were less in the lingually based triangular flap group at $12 \mathrm{hr}$ postoperatively but the difference was statistically insignificant. (10)

In this study the buccally based triangular flap showed higher incidence for wound dehiscence than the lingually based triangular flap but the difference was statistically insignificant this was predictable as the lingually based triangular flap designs placed all lines of incisions on sound bone .Very few studies in the literature have assessed wound dehiscence during the early wound healing period .After the impacted third molar surgery wound dehiscence may occur distal to the neighboring second molar during the first phase of wound healing. This region may undergo secondary healing without any additional discomfort or consequences. However, such dehiscence may lead to the development of alveolar osteitis, compromise the periodontal status of the adjacent tooth, and potentially prolong the postoperative treatment period. (25)

Sandhu et al. compared the effects of the envelope and bayonet flap designs on postoperative wound dehiscence. They found that wound dehiscence occurred significantly more frequently in the envelope flap group (35\%) when compared to the bayonet flap group (5\%). Jake et al.10 found that wound dehiscence developed in $57 \%$ of cases in which the envelope flap was used, but in only $10 \%$ of cases in which the modified triangular flap was used. SuarezCunqueiro et al also stated that wound dehiscence occurred in $14.8 \%$ of para-marginal flap cases, whereas none occurred with the use of a marginal flap. Yolcu et al. found that dehiscence incidence between the lingual-based triangular flap and the buccal base triangular flap was not statistically significant. This is consistent with our results. $(26,27,28)$

The incidence of dry socket formation was low in both groups however it was slightly higher in the buccally based triangular flap group which was predicted as this flap showed higher incidence for wound dehiscence. So, the development of alveolar osteitis was more likely but the difference was statistically insignificant.

Damage to the lingual nerve after third molar extraction is a rare complication. However, the incidence of lingual nerve damage shows variability across clinical studies. In the present study, lingual nerve damage did not occur in any of the study group patients, although the number of cases was not sufficient to evaluate this parameter. However, it was observed that the lingually based triangular flap was more secure in the prevention of lingual nerve damage, because the incision, dissection, and suturing were performed away from the lingual side. (23)

D. Menziletoglu et al.performed a study on 30 patients (24 females, 6 males) aged between 18-26 years to compare the effect of the lingual-based triangular flap with buccal-based triangular flap on postoperative complications in impacted third molar surgery. They found that the lingualbased triangular flap technique had more pain, swelling, trismus and operation time than the buccal-based triangular flap technique. Even though the risk of dehiscence appears to be less common in this technique, the quality of life of patients is very low. It is more appropriate to prefer the buccal based triangular flap in the third molar surgery. Also, patients' responses to the global life scale were no good in their study group. Twenty-six patients stated that quality of life decreased after impacted third molar surgery with lingual-based triangular flap. Their results were the exact opposite of our study results. (29)

\section{CONCLUSIONS}

From the outcomes of this study, it was decided that: lingually based triangular flap design displayed better postoperative healing and recovery than buccally based triangular flap design.

\section{CONFLICT OF INTEREST}

The writers state that they have no conflicts of interest.

\section{REGISTRATION}

This clinical trial was registered at clinical trial .gov under the number NCT04192864 and under the name of Comparison Between the Lingually Based and the Buccally Based Triangular Flap Design in the Surgical Removal of Impacted Mandibular Third Molars.

\section{FUNDING}

All the materials required for the study were supplied by the oral and maxillofacial surgery division in Alexandria University.

\section{REFERENCES}

1.Lopes V, Mumenya R, Feinmann C, Harris M. Third molar surgery: an audit of the indications for surgery, postoperative complaints and patient satisfaction. $\mathrm{Br} \mathrm{J}$ Oral Maxillofac Surg.1995;33:33-5.

2. Shevel E, Koepp WG, Bütow KW. A subjective assessment of pain and swelling following the surgical removal of impacted third molar teeth using different surgical techniques. SADJ. 2001;56:238-41.

3. Bello SA, Adeyemo WL, Bamgbose BO, Obi EV, Adeyinka AA. Effect of age, impaction types and operative time on inflammatory tissue reactions following lower third molar surgery. Head Face Med. 2011;28:7-8.

4. Amin MM, Laskin DM. Prophylactic use of third molars indomethacin for prevention of postsurgical complications after removal of impacted third molars. Oral Surg Oral Med Oral Pathol. 1983;55:448-51.

5. Sortino F, Cicciu M. Strategies used to inhibit postoperative swelling following removal of impacted lower third molar. Dent Res J (Isfahan). 2011;8:162-71. 
6. Kirk DG, Liston PN, Tong DC, Love RM. Influence of two different flap designs on incidence of pain, swelling, trismus, and alveolar osteitis in the week following third molar surgery. Oral Surg Oral Med Oral Pathol Oral Radiol Endod. 2007;104:e1-6.

7. Suarez-Cunqueiro MM, Gutwald R, Reichman J, OteroCepeda XS, Schmelzeisen R, Compostela S. Marginal flap versus paramarginal flap in impacted third molar surgery: a prospective study. Oral Surg Oral Med Oral Pathol Oral Radiol Endod. 2003;95:403-8.

8. Roode GJ, Butow K. An alternative surgical flap design for impacted third molars: a comparison of two different surgical techniques. SADJ. 2010,65: 246,248-51.

9. Briguglio F, Zenobio EG, Isola G, Briguglio R, Briguglio E, Farronato D, et al. Complications in surgical removal of impacted mandibular third molars in relation to flap design: clinical and statistical evaluations. Quintessence Int. 2011;42:445-53.

10. Yolcu Ü, Acar AH. Comparison of a new flap design with the routinely used triangular flap design in third molar surgery. Int J Oral Maxillofac Surg. 2015;44:1390-7.

11. Baqain ZH, Al-Shafi A, Hamdan A, Sawair A. Flap design and mandibular third molar surgery: a split mouth randomized clinical study. Int J Oral Maxillofac Surg. 2012;41:1020-4.

12. Ryabko BY, Stognienko VS, Shokin YI. A new test for randomness and its application to some cryptographic problems. J Stat Plan Infer. 2004;123:365-76.

13. Koymen R, Ortakoğlu K, Okcu KM, Altuğ HA, Aydıntuğ YS. Wound closure by skin traction. Turk J Med Sci 2002;32:179-81.

14. Van Gool AV, Ten Bosch JJ, Boering G. Clinical consequences of complaints and complications after removal of the mandibular third molar. Int J Oral Surg. 1977;6:29-37.

15. Azaz B, Shteyer A, Piamenta M. Radiographic and clinical manifestations of the impacted mandibular third molar. Int JOral Surg. 2017;5:153-60.

16. Monaco G, Daprile G, Tavernese L, Corinaldesi G, Marchetti C. Mandibular third molar removal in young patients: an evaluation of 2 different flap designs. J Oral Maxillofac Surg. 2009;67:15-21.

17. Seymour RA, Walton JG. Pain control after third molar surgery. Int J Oral Surg. 1984;13:457-85.

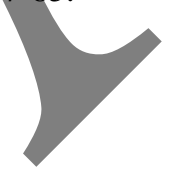

18. Erdogan O, Tatlı U, Ustun Y, Damlar I. Influence of two different flap designs on the sequelae of mandibular third molar surgery. Oral Maxillofac Surg. 2011;15:147-52.

19. Mangla M, Rajput L, Kumar A, Rathi V, Jain H, Kumar S. Lingual Triangular Flap vs Triangular Flap: A pilot study. Int J Oral Health Med Res. 2017;4:62-4.

20. Garcia AG, Sampedro FG, Rey JG, Torreira MG. Trismus and pain after removal of impacted lower third molars. J Oral Maxillofac Surg. 1997;55:1223-6.

21. Conard SM, Blakey GH, Shugars DA, Marciani RD, Phillips C, White RP. Patients' perception of recovery after third molar surgery. J Oral Maxillofac Surg. 2017;57:1288-94.

22. Dolanmaz D, Esen A, Isik K, Candirli C. Effect of 2 flap designs on postoperative pain and swelling after impacted third molar surgery. Oral Surg Oral Med Oral Pathol Oral Radiol. 2013;116:244-6.

23. Bouloux GF, Steed MB, Perciaccante VJ. Complications of third molar surgery. Oral Maxillofac Surg Clin North Am. 2007;19:117-28.

24. Kumar B S, T S, M V, Raman U. To Compare Standard Incision and Comma Shaped Incision and Its Influence on Post-Qperative Complications in Surgical Removal of Impacted Third Molars. J Clin Diagn Res. 2013;7:1514-8.

25. Mansuri S, Mujeeb A, Hussain SA, Hussain MA. Mandibular third molar impactions in male adults: Relationship of Operative time and Types of impaction on inflammatory complications. J Int Oral Health. 2014;6:915.

26. Suarez-Cunqueiro MM, Gutwald R, Reichman J, OteroCepeda LS, Schmelzeisen R, de Compostela S. Marginal flap versus paramarginal flap in impacted third molar surgery: a prospective study. Oral Surg Oral Med Oral Pathol Oral Radiol Endod 2003: 95: 403- 408.

27. Kirk DG, Liston PN, Tong DC, Love RM. Influence of two different flap designs on incidence of pain, swelling, trismus and alveolar osteitis in the week following third molar surgery. Oral Surg Oral Med Oral Pathol Oral Radiol Endod 2007: 104: e1-e6

28. Al-Samman AA. Can Flap Design Affects Patient Morbidity Following Mandibular Third Molar Surgery? Smile Dent J. 2016;11:18-21.

29. Menziletoglu D, Guler A, Basturk F, Isik B, Erdur E. Comparison of two different flap designs for bilateral impacted mandibular third molar surgery. Journal of Stomatology, Oral and Maxillofacial Surgery. 2019. 